\title{
The Influence Of Store Characteristics On Consumers' Impulse Buying Behaviour
}

\author{
Begzod Nishanov, Umidjon Ahunjonov \\ Department of Marketing, Westminster International University in Tashkent
}

\begin{abstract}
2016 Research Leap/Inovatus Services Ltd.

All rights reserved.

The current research aims to explore the influence of in store characteristics on consumer impulse buying behaviour. Precisely, this paper investigated the impact of window display, promotional signage, store layout, music and store smell on consumer impulse buying behaviour. The research was conducted among 117 customers of korzinka.uz supermarket using questionnaire which was

DOI: $10.18775 /$ jibrm.1849-8558.2015.13.3002

URL: http://dx.doi.org/10.18775/jibrm.18498558.2015.13.3002 formulated based on the previous literature. The collected data was analyzed using factor analysis and linear regression tests. The research findings suggested that store characteristics including window display, promotional signage and scent play crucial role in stimulating the impulse buying behaviour

\section{Keywords:}

Consumer Impulsive Buying

Window Display

Promotional Signage

Store Layout
\end{abstract}

Store Background Music

Store Scent

\section{Introduction}

The retailing business in Uzbekistan has grown rapidly in recent years. Nowadays, majority of Uzbek consumers are choosing retail outlets, precisely, supermarkets in order to do their shopping. A large number of consumers have started switching from open bazaars to supermarkets, since these types of retail outlet offer convenience, comfort and affordable prices for every day shopping. In response to changing consumer buying behaviour, retailers are continuously seeking for new retail strategies and using different marketing tools in order to ensure that consumers will come back to the store again and again. In this regard, it is important to emphasize the role of store characteristics which directly influences consumers buying behaviour. According to Tinnie(2010) store characteristics include store layout, presence of salespeople, store atmospherics and store type. Precisely, store environment, design of the store, presentation and location of merchandise are considered to be important part of store characteristics. Another reason for retailers to design their stores and to use different marketing tools is to give stimulus to consumers to purchase the goods impulsively. According to Bellenger (1978) the consumers shopping behaviour is divided into two types including planned and impulse purchase based on where buying decision is made. Planned purchase decision is made before visiting the store, whereas impulse purchase decisions are made inside the store due to the in store stimuli (cited in Raposo, 2013). Consumers' stimuli to buy things impulsively are triggered through store layout, signage (category, promotional, point of sale), feature areas (window display, promotional area, and entrance), visual merchandising and store atmosphere (lighting, color, music, scent). Therefore, it is important for retailers to understand the impact of in-store characteristics on consumer impulse buying behaviour since impulse purchases constitute large percentage of supermarket sales. According to Bell (2010) supermarkets are found to be the places which represent large percentage of impulse purchases and $60 \%-70 \%$ of purchases in supermarkets are made as a result of exposure to in-store stimuli. The aim of this paper is to investigate the influence of in-store characteristics on consumers' impulse buying behaviour using the case of Korzinka.uz supermarket. Another important reason to study the influence of in-store stimuli on consumers' impulse buying using the case of Korzinka.uz supermarket is to provide suggestions on how to further improve store characteristics based on research outcomes.

\section{Research question:}

How do store characteristics influence consumers' impulsive buying behavior?

Objectives:

1. To identify the influence of window display on consumer impulse buying behavior

2. To evaluate the impact of promotional signage on consumer impulse buying behavior

3. To measure the influence of store layout on consumer impulse buying behavior

4. To identify the impact of background music on impulse buying behavior 


\section{Literature Review}

Mohan (2013) described impulse buying as on the spot decision to buy a particular item with little thinking whereas unplanned buying may occur since customers often forget to include particular item in their shopping list and buy it remembering that they are out of stock.Moreover, impulsive purchases were defined as a consumers' response towards low-cost product offerings (Hausman, 2000).

The model of consumer buying is essential tool for us to understand the process of planned purchase. However, Kim (2003) modified these five consecutive processes to explain the process of impulse buying by dropping the stages of need recognition, information search and alternative evaluation. Instead of that, Kim (2003) reclassified the stages to browsing (product awareness), create desire, purchase decision, and post purchase evaluation. According to the impulse purchase model introduced by Kim (2003), impulse buying behavior of shoppers begins with product awareness where consumers start browsing the without planning to buy specific product. During this same process, they are exposed to well-designed store atmosphere. As a result, the urge to buy impulsively arises due to stimulus observed inside the store (Kim, 2003). There are several internal and external factors which are likely to stimulate the occasion of consumer impulse buying. Kim (2003) reported that internal factors include mood, desire hedonic pleasure perceived by consumers while external factors are described by visual merchandising, window display and promotional signage. (Figure $1)$.

\subsection{Factors influencing on impulse buying}

Due to increasing interest towards consumers' impulse buying behavior in retail outlets, a number of factors which trigger consumers' impulse buying behavior have been identified and analyzed. For instance, Tinnie (2010) used four types of factors in order to study consumers' impulse buying behavior in Bangladesh supermarkets. These factors are consumer characteristics, store characteristics, situational factors, and product characteristics. Consumer characteristics represent personality traits which are likely to increase impulse buying and include such variables as gender, age, culture, mood, shopping enjoyment and impulse buying tendency. Store characteristics consist of store layout, availability of salespeople, store atmospherics and store type. Another important factor mentioned by Tinnie, (2010) is situational factors which include time availability, money availability, presence of others and in-store browsing. Last factor which influences consumers' impulse buying is determined by product category and product price. Overall, 18 variables were used by Tinnie, (2010) to study consumers' impulse buying behavior. Research findings indicated that pricing strategies, in-store stimuli, promotional activities and situational factors are most likely to influence consumers' impulse buying behavior. In terms of store characteristics, window displays are found to have strongest influence on impulse buying; therefore, they need to be designed in an attractive way to draw the attention of consumers about new merchandise and price discounts. Also, this research highlighted the role of well-trained salespeople who help customers with their advices which in turn would lead to impulse purchase.

Zhuang (2006) studied the impact of situational factors on consumer buying decisions using the data from the shopping mall of USA, Hong Kong and China. Zhuang (2006) divided the factors into 2 main groups: situational (personality, gender, intellect) and non-situational (merchandise, smell, location, sound, visible configuration, presence of friends, mood, availability of cash, credit card). This study revealed that presence of friends or family members of consumers may help them to resolve their difficult purchasing problems, thus, increasing the chances of impulse buying. Precisely, the study found out that when consumers are accompanied by others they are prone to buy more products and spend more on impulse purchase.

Yarahmadi, (2011) analyzed the impact of four variables including window display, free product, cash discount and credit card on consumer impulse behavior using the sample size of 275 in Iran shopping mall. Yarahmadi (2011) developed questionnaire using likert scale type questions in order to collect data. In order to ensure reliability and validity of the research instruments, Cronbach alpha test and factor analysis was used. Cronbach alpha test was used to measure the internal consistency among questions used in the scale while factor analysis was applied to ensure construct validity (Yarahmadi, 2011). The findings of his research suggested window display is regarded as the strongest variable which influences consumer impulse behavior among others.

Mehta (2014) studied the impact of in-store characteristics including window display, store front, store environment and promotional signage on consumer impulse buying using the case of furniture outlets with the sample size 385. Mehta (2014) used consumer purchase behavior as dependent variable whereas the window display, store front, promotional signage and store atmosphere was regarded as independent variable. Each of these variables are measured on likert scale constructs ranging from $1=$ never to $5=$ frequently (Mehta, 2014). Mehta (2014) used Cronbach alpha test to test the reliability of the scales while factor analysis was used to check construct validity. For testing hypotheses, linear regression was used. The study by Mehta (2014) revealed that window display and promotional signage have direct relationship with consumers' impulse buying.

Mohan (2013) studied the impact of store environment on impulsive buying behavior. Precisely, he measured the influence of music, light, layout and retail staff on impulse purchases along with individual characteristics including impulse buying tendency and shopping enjoyment tendency. Likewise, Abratt (1990) discovered that store layout was the strongest factor to influence on impulse buying among other store environment characteristics. In his work, Abartt (1990) emphasized the role of in-store stimuli including position of merchandise, price discounts, and in-store demonstrations which affect impulse behavior. 
Review of several literatures in the field of impulse buying provided the evidence of several factors which are certain to influence on consumer impulse buying. Particularly, Muruganantham (2010) proposed a model which explained the impact of four main factors on impulse buying behavior. These factors include external factors, internal factors, situational factors, demographics and socio cultural factors. External factors can be defined as store related factors used by retailers to stimulate the impulse behavior whereas internal factors represent the emotions, mood, shopping enjoyment and feelings of customers. Situational factors include availability of time, money and presence of close friends or relatives whose advices are most likely to influence on impulse buying. Age, gender and culture can be attributed to demographic factors influencing impulse buying behavior of consumers.

In this regard, considerable amount of attention should be paid to the influence of external factors. Precisely, external factors, in other words, store characteristics (store layout, window display, sales promotions and store atmosphere) have been one of the crucial points for discussion for many years among the many researchers (Tinnie ,2010; Zhuang, 2006, Yarahmadi, 2011; Mohan 2013)who investigated the process of consumer impulse buying. The importance of store characteristics is always under the consideration of retailers since retailers use these characteristics as marketing tools to influence on consumer buying. For example, well designed and eye catching window displays are considered to be useful in terms of attracting the attention of customers and encourage them to enter the store. Once customers visit the store, the role of other external factors such as promotional signage, background music and store smell comes into force which can increase the chances of consumer impulse buying. Therefore, this paper aims to focus on the influence of external factors, precisely, store characteristics such as window display, promotional signage, store layout, music and scent in order to explain the process of impulse buying.

\subsection{Research Hypotheses \\ 2.2.1 Window display}

Window displays are used in the façade of the store through which retailers use to draw the customers into the store and provide message about the products offered inside the store (Levy and Weitz, 2002).According to Cornelius (2010), welldesigned storefront window displays are regarded as useful technique to attract the attention of new customers and motivate them to visit the store (cited in Levy and Weitz, 2002). Findings of the research conducted by Mehta (2014) suggested that there are positive relationship between window display and impulse buying. Therefore, this research proposed following hypothesis:

\section{H1: Impulse buying behavior of customers are influenced by window display}

\subsubsection{Promotional Signage}

According to Levy and Weitz (2002) promotional signage gives information about special offers and price discounts offered in the store. Yu and Bastin (2010) investigated the influence of
Point of Purchase (POP) posters in supermarkets and stated that in store promotion techniques such as in-store settings, reduced price promotions and coupons increase consumers' impulse buying tendency (cited in Mururganantham, 2013). Therefore, it was hypothesized:

\section{H2: Impulse buying behavior of customers are influenced by promotional signage}

\subsubsection{Store layout}

According to Bitner (1992) and Spies et. al (1997) good store layout enables customers' to find the product that they need in quick manner (cited in Mohan, 2013) . Moreover, Baker (2012) stated that well organized store layout enhances the process of shopping by creating convenience for customers (cited in Mohan, 2013). However, in most supermarkets daily needed products such as bread and milk are placed in back of the store in order to make customers to browse through the store, consequently, increasing the cases of impulse buying (Levy and Weitz, 2002). To investigate this issue, following hypothesis was set:

\section{H3: Impulse buying behavior of customers are influenced by store layout}

\subsubsection{Store background music}

Music is considered as an important element of store atmosphere which directly influences consumer buying behavior (Levy and Weitz, 2002). Matilla and Wirtz (2001) discovered that music can influence on impulse behavior as well. According to the findings of Matilla and Wirtz (2001) consumers spend are more likely to stay longer in store due to the presence of good background music and browse through the store looking at the merchandise. As a result, good background music triggers the senses of consumers by stimulating the process of impulse buying. Thus, below mentioned hypothesis was proposed:

H4. Impulse buying behavior of customers are influenced by store background music

\subsubsection{Store scent}

As well as music, store smell also directly influences consumers' emotions and moods (Levy and Weitz, 2002). Pleasant aroma of the store makes customers to spend more time looking through merchandise, which will result in impulse buying. The impact of store smell on impulse buying behavior was identified in the study of Matilla and Wirtz (2008) and Mohan (2013). Hence, this research hypothesized that:

H5. Impulse buying behavior of customers are influenced by store scent

\section{Methodology}

128 consumers of Korzinka.uz supermarket located in Yuzrabod street, participated in the survey. Since this research used the case of Korzinka.uz supermarket, convenience sampling method of non-probability sampling was applied. 117 questionnaires out of 128 were completed appropriately and they were used for data 
analysis; remaining 11 questionnaires were not included as they were completed in wrong format. Demographic characteristics of 117 respondents represent $56 \%$ of males, $44 \%$ of females. $25 \%$ of respondents aged $18-25 ; 34 \%$ of them are aged between $26-33$; $30 \%$ of them are aged between $34-41 ; 11 \%$ of them are aged $42-$ 49 years old.

The model for the current research is adopted from the study of Kim (2003)

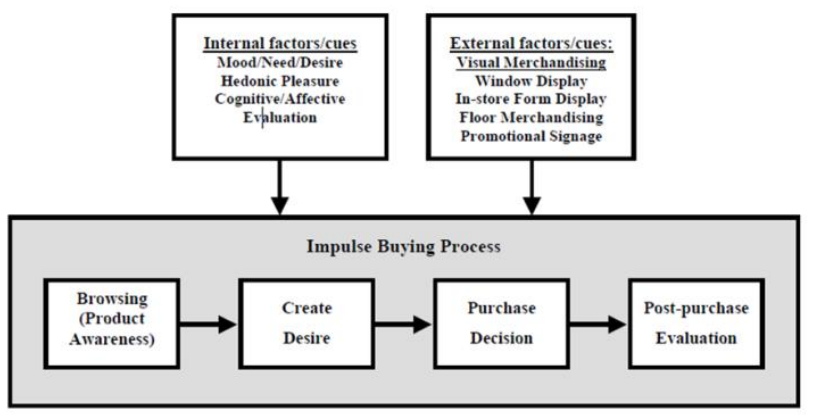

Figure 1:Impulse buying model (Source: Kim (2003)

\section{RESULTS}

\begin{tabular}{|l|l|}
\hline Items & Impulse buying \\
\hline $\begin{array}{l}\text { Sometimes I feel like buying things on } \\
\text { the spur of the moment. }\end{array}$ & .822 \\
\hline "I see it, I buy it" describes me. & .804 \\
\hline $\begin{array}{l}\text { "Just do it" describes the way I buy } \\
\text { things. }\end{array}$ & .791 \\
\hline I often buy things without thinking. & .776 \\
\hline I carefully plan most of my purchases. & .771 \\
\hline $\begin{array}{l}\text { I buy things according to how I feel at } \\
\text { the moment. }\end{array}$ & .752 \\
\hline $\begin{array}{l}\text { "Buy now, think about it later" describes } \\
\text { me. }\end{array}$ & .742 \\
\hline $\begin{array}{l}\text { Sometimes I am a bit reckless about } \\
\text { what I buy. }\end{array}$ & .652 \\
\hline I often buy things spontaneously. & .593 \\
\hline Eigenvalue & 5.03 \\
\hline Variance & $56 \%$ \\
\hline Cronbach $\alpha$ & 0.89 \\
\hline
\end{tabular}

A principal component analysis (PCA) was conducted on the 9 items with varimax rotation. KMO proved positive result for sampling adequacy, $\mathrm{KMO}=860$, "great" according to Field (2005). 9 items related to impulse buying loaded in one component, with factor loadings higher than .050 and eigenvalues higher than 1 with $56 \%$ variance explained.

\begin{tabular}{|c|c|c|c|c|}
\hline Items & Scent & $\begin{array}{l}\text { Prom } \\
\text { otion } \\
\text { al } \\
\text { Signa } \\
\text { ge }\end{array}$ & $\begin{array}{l}\text { Music } \\
\text { and } \\
\text { Layou } \\
\mathrm{t}\end{array}$ & $\begin{array}{l}\text { Windo } \\
\text { w } \\
\text { Displa } \\
\text { y }\end{array}$ \\
\hline $\begin{array}{l}\text { If scent of korzinka.uz is } \\
\text { pleasant I intend to go back } \\
\text { to the store in future }\end{array}$ & .832 & & & \\
\hline $\begin{array}{l}\text { If I like the music inside } \\
\text { korzinka.uz my chances of } \\
\text { unplanned buying become } \\
\text { greater }\end{array}$ & .791 & & & \\
\hline $\begin{array}{l}\text { The scent coming from the } \\
\text { Korzinka.uz entices me to } \\
\text { go inside }\end{array}$ & .737 & & & \\
\hline $\begin{array}{l}\text { If korzinka.uz smells good, } \\
\text { I tend to stay longer and } \\
\text { look at the merchandise }\end{array}$ & .584 & & .527 & \\
\hline $\begin{array}{l}\text { Layout of korzinka.uz is } \\
\text { well-structured so that } \\
\text { consumers have no } \\
\text { difficulty finding their way }\end{array}$ & .558 & & & \\
\hline $\begin{array}{l}\text { I am more likely to make } \\
\text { unplanned buying if the } \\
\text { Korzinka.uz smells good }\end{array}$ & & & & \\
\hline $\begin{array}{l}\text { I am more likely to make } \\
\text { unplanned buying if the } \\
\text { product has a sale sign }\end{array}$ & & .791 & & \\
\hline $\begin{array}{l}\text { Walking space in } \\
\text { korzinka.uz is not crowded }\end{array}$ & & .747 & & \\
\hline $\begin{array}{l}\text { If I see an interesting offer } \\
\text { on in-store signs of } \\
\text { Korzinka.uz, I am more } \\
\text { likely to buy it }\end{array}$ & & .621 & & \\
\hline $\begin{array}{l}\text { Sales signs used by } \\
\text { Korzinka.uz entices me to } \\
\text { look through the } \\
\text { merchandise }\end{array}$ & & .567 & & \\
\hline $\begin{array}{l}\text { The music playing in the } \\
\text { Korzinka.uz influences my } \\
\text { impulse buying behavior }\end{array}$ & & & .768 & \\
\hline $\begin{array}{l}\text { I spend more time in the } \\
\text { Korzinka.uz browsing it, if } \\
\text { I like the ambience and the } \\
\text { background sounds }\end{array}$ & & & .636 & \\
\hline $\begin{array}{l}\text { When I enter a } \\
\text { Korzinka.uz, I tend to } \\
\text { follow the store layout } \\
\text { while browsing the store }\end{array}$ & & & .632 & \\
\hline $\begin{array}{l}\text { Korzinka.uz store makes } \\
\text { me feel like exploring it }\end{array}$ & & & .592 & \\
\hline $\begin{array}{l}\text { I am more likely to enter } \\
\text { korzinka.uz, if it has an } \\
\text { eye-catching window } \\
\text { display }\end{array}$ & & & & .853 \\
\hline $\begin{array}{l}\text { When I see a special } \\
\text { promotional signage in } \\
\text { Korzinka.uz, I go to look at } \\
\text { the product }\end{array}$ & & & .504 & .635 \\
\hline $\begin{array}{l}\text { I feel compelled to visit } \\
\text { korzinka.uz, if it has an } \\
\text { interesting window display }\end{array}$ & & & & .624 \\
\hline $\begin{array}{l}\text { I pay attention to } \\
\text { korzinka.uz's window } \\
\text { display }\end{array}$ & & & & .610 \\
\hline Eigenvalues & 7.09 & 1.9 & 1.3 & 1.02 \\
\hline Variance & 18 & 17 & 15 & 15 \\
\hline Cronbach $\alpha$ & 0.77 & 0.78 & 0.78 & 0.79 \\
\hline
\end{tabular}

Items included in the questionnaire also loaded into 4 components. Only factor loadings higher than 0.50 was extracted. Items related to Scent loaded in the first component labeled as "Scent", component 2 represented items as "promotional signage" while component 4 represented window display. 
However, items related to music and layout was represented under same factor, therefore it was decided to name this factor as music since items on music has higher factor loadings.

Based on the output of factor analysis, factor scores were further used in regression analysis.

\subsection{Regression analysis}

4.1.1 The influence of Window Display on consumer impulse buying

The results of linear regression analysis also showed there was a significant relationship between consumer impulse buying and window display. Since p valuefrom regression analysis was less than alpha level 0.01 , it can be stated that research hypothesis was accepted.

\subsubsection{The influence of promotional signage on consumer impulse buying}

The outcomes of linear regression analysis discovered that promotional signage used in store significantly impacts consumer impulse buying behavior $\mathrm{p}$ value of regression analysis was less compared to alpha level 0.05 . Hence, this research provided enough evidence to prove the hypothesis that impulse buying behavior of customers was influenced by promotional signage.

\subsubsection{The influence of store layout on consumer impulse buying}

The analysis of regression for the given sample showed that there was no significant relationship between store layout and consumer impulse buying behavior. Thus, the null hypothesis was accepted

\subsubsection{The influence of music on consumer impulse buying}

The results of regression analysis revealed that there was no any significant relationship between impulse buying and background music, with $\mathrm{p}$ value (0.31) greater than alpha level $\mathrm{p}>0.05$. Therefore, the collected data in this research did not show any relationship between impulse buying and music. Therefore, the null hypothesis was accepted

\subsubsection{The influence of store smell on consumer impulse buying} Regression analysis also revealed significant positive relationship between impulse buying and store smell. The $p$ value of regression analysis was less than alpha level $\mathrm{p}<0.005$. Therefore, the data collected in this investigation provide enough proof to accept the hypothesis which describes the significant impact of store smell to impulse buying tendency of customers.

\begin{tabular}{|l|c|c|}
\hline Hypotesis & Coefficient & p-value \\
\hline $\begin{array}{l}\text { H1. Impulse buying behavior of } \\
\text { Korzinka.uz customers are } \\
\text { influenced by window display }\end{array}$ & 0.436 & $0.005^{* * *}$ \\
\hline $\begin{array}{l}\text { H2. Impulse buying behavior of } \\
\text { Korzinka.uz customers are } \\
\text { influenced by promotional } \\
\text { signage }\end{array}$ & 0.187 & $0.023^{* *}$ \\
\hline $\begin{array}{l}\text { H3. Impulse buying behavior of } \\
\text { Korzinka.uz customers are }\end{array}$ & -0.105 & 0.317 \\
\hline
\end{tabular}

\begin{tabular}{|l|c|c|}
\hline influenced by store layout & & \\
\hline $\begin{array}{l}\text { H4. Impulse buying behavior of } \\
\text { Korzinka.uz customers are } \\
\text { influenced by store background } \\
\text { music }\end{array}$ & -0.105 & 0.317 \\
\hline $\begin{array}{l}\text { H5. Impulse buying behavior of } \\
\text { Korzinka.uz customers are } \\
\text { influenced by store smell/scent }\end{array}$ & 0.283 & $0.018^{* *}$ \\
\hline
\end{tabular}

\section{Conclusions}

The influence of window display on consumer impulse buying behavior

The research revealed significant relationship between impulse buying and window display, which was supported by the analysis of regression. Previous studies by Tinnie (2011), Mehta (2014) and Bhatti (2013) discovered significant positive relationship between impulse buying and window display. Results of the research implied that if customers see an attractive and interesting window display, they are more likely to visit the store. Consequently, they tend to make an unplanned purchase. Furthermore, customers make important decisions whether to shop or not in particular store by paying attention to the window display. Window displays of Korzinka.uz stores are mainly designed and decorated with the images of people, family members, friends and young couples who are browsing through the store or touching particular product while shopping. Moreover, façade of Korzinka.uz is decorated with images of merchandise placed in the shelf and wide assortment of goods which also attracts the attention of customers. When customers see the images of merchandise placed in window display or any new product, they are more likely to visit the Korzinka.uz in order to become familiar with its price, quality, and country of origin. In other words, customers are more likely to enter the korzinka.uz in order to get information about particular product category which he is interested in to buy. While customers look for information about particular product category by browsing the store, they become exposed to other products as well, which may lead them to buy particular products impulsively. Therefore, design of the window display is considered to be crucial factor in stimulating the impulse purchase behavior of customers

The influence of promotional signage on consumer impulse buying

The research proposed hypothesis about the positive relationship between promotional signage and impulse buying. Precisely, it was described that impulsive buying behavior of customers are influenced by promotional signage. The research findings implied that there was a significant relationship between impulse buying and promotional signage. In other words, it indicates that increasing number of in-store promotions and discounts are more likely to influence positively on impulse purchase intentions of customers. The influence of promotional signage on customer impulse buying was investigated in the research of Mehta (2013), Yarahmadi (2011), Zhou and Wong (2003), For instance, findings of the research by Zhou and Wong (2003) indicated that point of purchase posters positively influences consumer impulse buying. Precisely, point of purchase posters are considered as special form of sales promotions that can be found near the supermarket entrance and checkout areas. The significant relationship between consumer impulse buying and promotional signage found in this research can be explained by the fact that 
Korzinka.uz chains offer sales promotions for the customers on continuous basis. Similarly, Arkes (1994) found out that when customers see price discounts, they are more likely to purchase discounted products without much thinking and consideration (cited in Tendai, 2009). Therefore, this study concluded that when customers see products with sales signs or price reductions in supermarket, they are more likely to buy these products impulsively.

\section{The influence of store layout on consumer impulse buying}

The research hypothesized positive relationship between impulse buying and store layout of. However, the findings of the research found no relationship between store layout and consumer impulse buying behavior. The layout of korzinka.uz supermarket is formulated on the basis of grid layout. Grid layout is often formulated by placing supermarket aisles parallel to each other and a checkout area is placed at the front side where shoppers enter and exit (Levy and Weitz, 2002). Grid layout is often considered to be convenient for customers who want to find particular product easily by spending as much less time as possible. Secondly, usage of grid layout format is cost efficient for many retailers since most of the space will be allocated for merchandise position (Levy and Weitz, 2002). However, there are certain disadvantages of grid layout. According to Levy and Weitz (2002) grid layout does not stimulate the impulsive behaviour of customers because height of shelves prevents the customers to observe the products placed in other shelves. Therefore, customers only browse through products located in one aisle. Once the customers easily find the product they need, they are more likely to leave the store without making any unplanned purchase. The disadvantages of grid layout provided by Levy and Weitz (2002) can be regarded as a good explanation to support the findings of current study.

\section{The influence of background music on consumer impulse buying}

The research aimed to investigate the impact of store background music on consumer impulse buying behaviour. The outcomes of the research suggested that there was no significant relationship between music played in korzinka.uz store and consumer impulse buying. The results of the research were supported by linear regression analysis which did not show any relationship between store background music and consumer impulse buying. However, the findings of several studies including Mohan (2013), Baker (1994) Matilla (2001), Tinnie (2010) considered music as one of the important store environment characteristics which directly influenced on moods and feelings of customers by resulting in shopping enjoyment. The outcomes of study by Tinnie (2010) reported that high volume music played in the store is considered to be important in encouraging the impulse buying behavior of customers. However, Astos (2000) stated that loud music is found to influence negatively on shopping intentions of customers (cited in Mohan, 2013). Therefore, it can be stated that the genre and tempo of music played in the store directly influence on moods of customers. Since the research used convenience sampling method, the participants of the survey are more likely to be interested in the other genre of music than the one played in korzinka.uz. Since they are not interested in the music played in store, their impulse buying behavior may not be related to the music.

The influence of store scent on consumer impulse buying The current research proposed the positive relationship between store scent and consumer impulse buying. The findings of the research implied that there was a significant positive relationship between consumer impulse buying and store smell. Precisely, pleasant store smell influences positively on the emotions and moods of customers by encouraging their impulse purchases. The results of previous studies in the field of impulse buying behavior also support this finding (Mohan, 2013; Tinnie, 2010; Baker, 1994; Matilla and Wirtz, 2001). According to Matilla and Wirtz (2001), it is important to highlight the presence of ambient scent in stores, which ultimately influences on buying behaviour of customers. Ambient scent is considered to be present in store environment including the scent of grapefruit and citrus fragrances and it does not relate to any product specific scent (Matilla and Wirtz, 2001). Presence of pleasant ambient smell in the store makes customers to spend more time looking through merchandise. Consequently, impulse buying behaviour of customers is more likely to arise due to exposure to store smell. Furthermore, it is important to mention the presence of pleasant store smells in each product category of supermarkets. For instance, customers passing by bakery section of the store are more likely to decide on the spur of moment to purchase biscuits, cookies and breads due to their pleasant smell. Therefore, it can be concluded that presence of pleasant store smell positively influences on the mood of customers by encouraging their impulse buying.

The results of research identified significant relationships between store characteristics and impulse buying behaviour of customers. The findings of the research can be used by store managers, particulary store managers of korzinka.uz, in order to further enhance store environment and create convinient shopping experience for customers.

There are some limitations in this paper that should be outlined. The survey was conducted only in one chain store of Korzinka.uz with the participation of 117 respondents. Therefore, it is suggested that future research can be conducted in a multiple chain stores of Korzinka.uz supermarket with larger sample sizes in order to ensure the generalisabilty of the research outcomes. For example, the research did not identify any significant relationship between store music and impulse buying.

Conducting the same survey with larger sample size may produce significant result in terms of relationship of music with impulse buying which can be consistent with the outcomes of previous literatures. Furthermore, the current study only focused on the influence of in store characteristics in order to describe consumer impulse buying. Therefore, the future research can take into account the importance of other factors such as situational including time availabilty, money availabilty and presence of 
others in order to analyze the consumer buying behaviour of customers on wider context alongside store characteristics.

\section{References}

- Abratt, R., (1990). Unplanned buying and in-store stimuli in supermarkets.Managerial and Decision Economics, 11 (2).pp.111-121. CrossRef

- Baker, J., Grewal, D. and Parasuraman, A. (1994). The Influence of Store Environment on Quality Inferences and Store Image. Journal of the Academy of Marketing Science, 22(4), pp.328-339 CrossRef

- Bell, D., (2010). Unplanned Buying on Shopping Trips, Journal of Marketing Science, 10 (4).pp.109118

- Bhatti, L. (2013). The impact of Visual Merchandising on Consumer Impulse buying behaviour. 4th Asia-Pacific Business Research Conference.30 September - 1 October 2013. Bayview Hotel, Singapore

- Field, A, (2005), Discovering Statistics Using SPSS, 2ndet, SAGE publications Inc, UK.

- Hausman, A., (2000). A multi-method investigation of consumer motivations in impulse buying behavior Journal of Consumer Marketing, 17 (5), pp.403 426, CrossRef

- Kim, J. (2003). College students apparel impulse buying in relation to visual merchandising [online]. Available from http://www.facsmail.org/ss/docs/kim_jiyeon_200308 _ms.pdf [Accessed 2 February, 2015]

- Levy and Weitz (2002).Retailing Management. 8th ed. USA, New York: The McGraw-Hill Companies.

- Mattila, A. and Wirtz, J. (2001).Congruency of scent and music as a driver of in-store evaluations and behavior.Journal of Retailing, 77(2), pp.273-289, CrossRef

- Mattila, A. and Wirtz, J. (2008).The role of store environmental stimulation and social factors on impulse purchasing.Journal of Services Marketing, 22(7), pp.562-567, CrossRef

- Mehta, N. (2013). Impact of Visual Merchandising on impulse buying behaviour of consumer: A Case from central Mall of Ahmedabad, Universal Journal of Management 1 (2), pp.76-82

- Mehta, N. (2014). Impact of Visual merchandising on Consumer buying: A study of furniture outlets, Universal Journal of Management 2 (6), pp. 207-217

- Mohan, G., Sivakumaran, B. and Sharma, P. (2013). Impact of store environment on impulse buying behavior.European Journal of Marketing, 47(10), pp.1711-1732, CrossRef

- Raposo, D., (2013). Drivers of snack foods impulse buying behaviour among young consumers, British Food Journal, 115 (9), pp.1233 - 1254, CrossRef

- Saunders, M. (2009), Research methods for business students, 5thed, Prentice-Hall, UK. 